\title{
Meningkatkan Motivasi Belajar Melalui Penerapan Model Belajar Jigsaw
}

\author{
Takiudin Zarkasi \\ Sekolah Tinggi Agama Islam Darul Kamal Lotim NTB \\ taqizar@yahoo.co.id
}

\begin{abstract}
This paper discusses the increasing students' learning motivation using a new learning model known as jigsaw learning on the subject of the Quran Hadith. The results of this study shows that the jigsaw method can foster students' learning motivation by itself, because in this study it provides an opportunity for all students to be actively involved in the thinking process and learning activities. By providing many opportunities for students to actively learn the group in memorizing short letters to make the students' ability to read and memorize to be good because there is a process of brainstorming and complementary reading and memorizing students.
\end{abstract}

Keywords: Learning Motivation, Jigsaw, the Quran, Hadith.

\section{Pendahuluan}

Pendidikan al-Qur'an di Madrasah Ibtidaiyah sebagai landasan yang integral dari pendidikan Agama, memang bukan satu-satunya faktor yang menentukan dalam pembentukan watak dan kepribadian peserta didik, tetapi secara substansial mata pelajaran al-Qur'an dan Hadis memiliki kontribusi dalam memberikan motivasi kepada peserta didik untuk mempraktikkan nilai-nilai keyakinan keagamaan (tauhid) 
dan akhlakul karimah dalam kehidupan sehari-hari. ${ }^{1}$ Mata pelajaran al-Qur'an Hadis adalah bagian dari mata pelajaran Pendidikan Agama Islam pada Madrasah Ibtidaiyah yang dimaksud untuk memberikan motivasi, bimbingan, pemahaman, kemampuan dan penghayatan terhadap isi yang terkandung dalam al-Qur'an dan Hadis, sehingga dapat diwujudkan dalam perilaku sehari-hari sebagai manifestasi iman dan takwa kepada Allah Swt. ${ }^{2}$

Dalam memelihara kesucian serta kemurnian al-Qur'an, Allah Swt memberikan kemudahan kepada hamba-hamba-Nya yang berminat dan sungguh-sungguh untuk menghafal kitab suci al-Qur'an. ${ }^{3}$ Pada dasarnya dalam keadaan normal, pikiran anak usia sekolah dasar berkembang secara berangsur-angsur dan secara tenang. Anak betul-betul ada dalam stadium belajar. Di samping keluarga, sekolah memberikan pengaruh yang sistematis terhadap pembentukan akal budi anak. Ingatan anak pada usia 8-12 tahun ini mencapai intensitas paling besar dan paling kuat. Daya menghafal dan daya memorisasi (dengan sengaja memasukkan dan meletakkan pengetahuan dalam ingatan) anak mampu memuat jumlah materi ingatan paling banyak. ${ }^{4}$

Namun, pembelajaran al-Qur'an Hadis terutama menghafal suratsurat pendek yang selama ini lebih mengarah kepada sifat dominan pada guru dengan banyak memakai metode ceramah resitasi dan sorogan sehingga kurang mampu menghafal dengan baik dan menjadikan siswa pasif. Pembelajaran al-Qur'an Hadis terutama menghafal suratsurat pendek yang paling penting peserta didik perlu melakukannya, memecahkan masalah sendiri, menemukan contoh-contoh, mencoba

\footnotetext{
1 Peraturan Menteri Agama Republik Indonesia No. 2 Tahun 2008 Tentang Standar Kompetensi Lulusan dan Standar Isi Pendidikan Agama Islam dan Bahasa Arab di Madrasah, 19.

2 Ibid.

3 Ilham Agus Sugianto, Kiat Praktis Menghafal al-Qur'an (Bandung: Mujahid, 2004), 5.

4 Kartini Kartono, Psikologi Anak, Psikologi Perkembangan (Bandung: Mandar Maju, 1995), 138.
} 
keterampilan-keterampilan dan melakukan tugas-tugas yang tergantung pada pengetahuan yang telah mereka miliki atau yang harus mereka capai. Oleh karena itu, dibutuhkan satu perubahan dalam memberikan pembelajaran kepada peserta didik, salah satunya yang bisa dilakukan dengan memberikan model pembelajaran baru yang dikenal dengan nama jigsaw learning, yaitu strategi pembelajaran kooperatif yang memungkinkan masing-masing siswa suatu kelompok mengkhususkan diri pada suatu materi pembelajaran. Dalam strategi ini guru memperhatikan latar belakang pengalaman siswa dan membantu semata agar bahan pelajaran menjadi lebih bermakna. ${ }^{5}$

Metode Jigsaw Learning karena metode ini mengarah pada peningkatan keaktifan belajar peserta didik baik secara individu maupun kelompok. Sebagai pendidik dan pengajar, senantiasa dituntut untuk mampu menciptakan iklim belajar mengajar yang kondusif, serta dapat memotivasi peserta didik dalam belajar mengajar yang akan berdampak positif dalam pencapaian prestasi hasil belajar secara optimal. Pendidik dapat menggunakan metode mengajar yang tepat, efektif, efisien untuk membantu meningkatkan kegiatan belajar mengajar serta memotivasi peserta didik untuk belajar dengan baik. ${ }^{6}$ Metode jigsaw learning yang diberikan pada pembelajaran al-Qur'an Hadis terutama menghafal surat-surat pendek akan terjadi proses pembelajaran aktif, yaitu proses pembelajaran tidak hanya pengajar yang menjadi sumber belajar satusatunya. Peserta didik diharapkan dapat melaksanakan apa yang menjadi tanggung jawabnya baik di dalam kelas maupun di luar kelas. Belajar bersama merupakan salah satu cara untuk memberikan semangat anak didik dalam menerima pelajaran dari pendidik. Anak didik yang tidak bergairah belajar seorang diri akan menjadi bergairah bila dia dilibatkan dalam kerja kelompok. ${ }^{7}$

5 Anita Lie, Cooperative Learning (Jakarta: Gramedia Widiasarana Indonesia, 2004), 69.

6 Slameto, Belajar dan Faktor-faktor yang Mempengaruhinya (Jakarta: Rineka Cipta, 1995), 65.

7 Syaiful Bahrie Djamarah, Pendidik dan Anak Didik Dalam Interaksi Edukatif (Jakarta: Rineka Cipta, 2000), 68. 


\section{Metode Jigsaw}

Sebelum dijelaskan tentang metode pembelajaran Jigsaw penulis akan menjelaskan terlebih dahulu tentang metode pembelajaran. Metode secara harfiah diartikan "cara”. Dalam pemakaian yang umum metode diartikan sebagai cara melakukan kegiatan atau cara melakukan pekerjaan dengan menggunakan fakta dan konsep-konsep secara sistematis. ${ }^{8}$

Sedangkan Jigsaw adalah salah satu tipe model pembelajaran kooperatif yang terdiri dari tim-tim belajar heterogen beranggotakan 45 orang (materi disajikan peserta didik dalam bentuk teks) dan setiap peserta didik bertanggung jawab atas penguasaan bagian materi belajar dan mampu mengajarkan bagian tersebut kepada anggota lain. ${ }^{9}$ Jigsaw telah dikembangkan dan diuji coba oleh Elliot Aronson dan teman-teman di Universitas Texas, dan teman-teman di Universitas John Hopkins pada tahun 1978. Jigsaw merupakan model pembelajaran kooperatif, dengan siswa belajar dalam kelompok kecil yang terdiri dari 4-6 orang secara heterogen. Materi pembelajaran yang diberikan kepada siswa berupa teks dan setiap anggota bertanggung jawab atas ketuntasan bagian materi pelajaran yang harus dipelajari. Teknik ini serupa dengan pertukaran antarkelompok. Tapi, bedanya setiap siswa mengajarkan sesuatu. Ini merupakan alternatif menarik bila ada materi belajar yang bisa disegmentasikan. Tiap siswa mempelajari setiap bagian yang bila digabungkan akan membentuk pengetahuan yang padu. ${ }^{10}$ Jigsaw didesain untuk meningkatkan rasa tanggung jawab siswa terhadap pembelajarannya sendiri dan juga pembelajaran orang lain. Siswa tidak hanya mempelajari materi yang diberikan, tetapi mereka juga harus siap memberikan dan mengajarkan materi tersebut pada anggota kelompoknya yang lain. Dengan demikian, "Siswa saling tergantung satu dengan yang lain dan harus

${ }_{8}$ Muhibbin Syah, Psikologi Pendidikan dengan Pendekatan Baru (Bandung: Remaja Rosda Karya, 1997), 201.

9 Hermin Budingrah, Kooperatif Learning (Bandung: Pustaka Setia, 2004), 29. Robert E. Slavin, Cooperative Learning (Bandung: Nusa Media, 2008), 235.

${ }^{10}$ Mel Siberrnen, 101 Strategi Pembelajaran Aktif (Active Learning), terj. Sarjuli dan Azfat Ammar (Jakarta: Yakpendis, 2001), 65. 
bekerja sama secara kooperatif untuk mempelajari materi yang ditugaskan." Pada model pembelajaran kooperatif tipe Jigsaw, terdapat kelompok asal dan kelompok ahli. Kelompok asal yaitu kelompok induk yang merupakan gabungan dari beberapa kelompok ahli. Kelompok ahli yaitu anggota dari kelompok asal berbeda yang mendapat tugas topik yang sama berkumpul dan berdiskusi tentang topik tersebut.

Dalam pembelajaran model Jigsaw peserta didik tidak hanya mempelajari materi yang diberikan, tetapi juga harus siap memberikan dan mengajarkan materi tersebut pada anggota kelompok yang lain. Para anggota dari tim yang berbeda dengan topik yang sama bertemu untuk berdiskusi saling membantu satu sama lain tentang topik pembelajaran yang ditugaskan mereka. Kemudian peserta didik kembali pada tim masing-masing untuk menjelaskan kepada anggota kelompok yang lain. Tentang apa yang telah mereka pelajari sebelumnya. Pada strategi pembelajaran kooperatif tipe Jigsaw, terdapat kelompok ahli hubungan antara kelompok asal. Para anggota dari kelompok asal yang berbeda bertemu dengan topik yang sama dalam kelompok untuk berdiskusi dan membahas materi yang ditugaskan pada masing-masing anggota kelompok, serta membantu satu sama lain untuk mempelajari topik mereka tersebut. Setelah pembahasan selesai, para anggota kelompok kemudian kembali kepada kelompok asal dan berusaha mengajarkan pada teman sekelompoknya apa yang mereka dapatkan saat pertemuan di kelompok ahli. Jigsaw didesain selain untuk meningkatkan rasa tanggung jawab peserta didik secara mandiri juga dituntut saling ketergantungan yang positif terhadap teman sekelompoknya selanjutnya diakhiri pembelajaran. Peserta didik diberi kuis secara individu yang mencakup materi setiap peserta didik terhadap anggota tim yang memberikan informasi yang diperlukan dengan tujuan agar dapat mengerjakan kuis dengan baik. ${ }^{11}$ Jadi metode Jigsaw adalah cara melaksanakan pembelajaran dengan menggunakan bentuk tim-tim belajar heterogen beranggotakan 4-5 orang untuk mengkaji materi.

\footnotetext{
${ }^{11}$ Slavin, Cooperative Learning, 237.
} 


\section{Dasar Metode Jigsaw}

Segala kegiatan pasti mempunyai tujuan dan dasar dalam melakukannya. Begitu juga dalam pelaksanaan pembelajaran model jigsaw juga terdapat dasar paedagogis dan dasar psikologis. Model Jigsaw mempunyai pendekatan secara kelompok. Belajar bertujuan mendapatkan pengetahuan, sikap kecakapan, dan keterampilan untuk mencapai tujuan tersebut diperlukan suatu metode atau cara. Dalam proses belajar mengajar metode belajar kelompok merupakan sebagai salah satu metode yang menggunakan pendekatan kelompok. Pendekatan kelompok digunakan untuk membina dan mengembangkan sikap sosial anak didik. Menurut Bimo Walgito dasar dari belajar kelompok dapat digolongkan menjadi dua yaitu:

\section{Dasar Yuridis}

Dasar yuridis sebagai dasar yang berkaitan dengan masalah pendidikan dan pengajaran. Hal tersebut tercermin dalam UU No. 20 Tahun 2003 tentang Sistem Pendidikan Nasional Pada pasal 1 berbunyi bahwa jenis pendidikan adalah kelompok yang didasarkan pada kekhususan tujuan pendidikan suatu tujuan. Sedangkan pasal 3 yang berbunyi "Pendidikan nasional berfungsi mengembangkan kemampuan dan membentuk watak, serta peradaban bangsa yang bermartabat dalam rangka mencerdaskan bangsa bertujuan untuk berkembangnya potensi peserta didik agar menjadi manusia yang beriman dan bertakwa kepada Tuhan Yang Maha Esa, berakhlak mulia, sehat, berilmu cakap, kreatif, mandiri, dan menjadi warga negara yang demokratis serta bertanggung jawab." Begitu juga terdapat dalam PP No. 19 Tahun 2005 tentang Standar Nasional Pendidikan Bab IV Pasal 19 berbunyi "Proses pembelajaran pada satuan pendidikan diselenggarakan secara interaktif, inspiratif, menyenangkan, menantang, memotivasi peserta didik untuk berpartisipasi aktif, serta memberikan ruang yang cukup bagi prakarsa, kreativitas dan kemandirian sesuai dengan bakat, minat, dan perkembangan fisik, serta psikologi peserta didik. 


\section{Dasar Psikologis}

Dasar psikologis akan terlihat pada diri manusia tercermin pada kehidupan sehari-hari. Kegiatan tersebut dapat digolongkan ke dalam tiga golongan utama secara hakiki, yaitu:

a. Kegiatan yang bersifat individual;

b. Kegiatan yang bersifat sosial;

c. Kegiatan yang bersifat ketuhanan. ${ }^{12}$

\section{Dasar Religius}

Selain dua dasar di atas, asas kooperatif juga memiliki asas agama yang termaktub dalam Q.S. al-Maidah ([5]: 2). "Dan tolong-menolonglah kamu dalam (mengerjakan) kebajikan dan takwa, dan jangan tolong-menolong dalam berbuat dosa dan pelanggaran."13 Dari ayat ini dapat diketahui bahwa prinsip kerjasama dan saling membantu dalam kebaikan juga sangat dianjurkan oleh agama (Islam).

\section{Langkah-Langkah Metode Jigsaw}

Langkah-langkah yang dipersiapkan dalam metode Jigsaw Learning sebagai berikut: ${ }^{14}$

1. Materi. Memilih satu atau dua bab, cerita atau unit-unit lainnya, yang masing-masing mencakup materi untuk dua atau tiga hari, kemudian membuat sebuah lembar ahli untuk tiap topik. Lembar ahli ini akan mengantarkan kepada siswa untuk berkonsentrasi saat membaca dan dengan kelompok ahli yang akan bekerja. Lembar ini berisi empat sampai enam topik.

\footnotetext{
12 Bimo Walgito, Bimbungan dan Penyuluhan di Sekolah (Yogyakarta: Andi Offset, 2000), 78.

${ }^{13}$ Soenarjo, et.al., Al-Qur'an dan Terjemahnya (Jakarta: Depag RI, 2005), 156.

${ }^{14}$ Slavin, Cooperative Learning, 238-241.
} 
2. Membagi siswa ke dalam kelompok asal. Membagi siswa ke dalam tim heterogen yang terdiri dari empat sampai enam anggota. Tim tersebut terdiri dari seorang siswa yang berprestasi tinggi, berprestasi sedang dan yang berprestasi rendah.

3. Membagi siswa ke dalam kelompok ahli. Kelompok ahli diambil dari kelompok asal yang berbeda, apabila jumlah siswa lebih dari enam maka kelompok ini dibagi menjadi dua supaya lebih maksimal.

Adapun kegiatan pembelajaran kooperatif tipe Jigsaw ini diatur secara instruksional sebagai berikut: ${ }^{15}$

1. Membaca. Para siswa menerima topik ahli dan membaca materi yang diminta untuk menemukan informasi yang berhubungan dengan topik mereka.

2. Diskusi kelompok ahli. Para siswa dengan keahlian yang sama bertemu untuk mendiskusikannya dalam kelompok-kelompok ahli.

3. Laporan tim. Para ahli kembali ke dalam kelompok mereka masingmasing (kelompok asal) untuk menyampaikan topik-topik mereka kepada teman satu timnya.

4. Tes. Setelah selesai dijelaskan pembelajaran, siswa harus menunjukkan apa yang dipelajari selama bekerja kelompok dengan menggunakan tes secara individual.

Langkah-langkah praktis pelaksanaannya sebagai berikut:

a. Persiapan

1) Guru memilih materi yang bisa dipecah atau disegmentasikan dalam beberapa bagian.

2) Menjelaskan sistem belajar yang akan dipakai

3) Membentuk home teams sebagai kelompok asal

\footnotetext{
${ }^{15}$ Ibid.
} 
4) Membentuk expert teams yang terdiri dari anggota-anggota kelompok yang mempelajari segmen yang sama dalam home teams masing-masing.

b. Pelaksanaan

1) Setelah siswa terbagi dalam beberapa kelompok, tiap segmen materi diberikan pada siswa dalam home teams.

2) Guru menginstruksikan siswa untuk mempelajari "bagian"nya secara mendalam dengan expert teams, yakni siswa yang mempelajari segmen yang sama.

3) Guru selalu memantau proses belajar siswa dalam setiap kelompok ahli sebagai bahan evaluasi bagi proses kelompok dalam kelas maupun untuk mengetahui sejauh mana keaktifan siswa.

4) Setelah proses belajar dalam expert teams usai, masingmasing siswa kembali ke kelompoknya masing-masing untuk mengajarkan apa yang telah didapat dari hasil belajar bersama anggota expert teams. Di dalam home teams siswa saling belajar dari rekannya mengenai segmen materi yang berbeda-beda.

5) Guru berfungsi sebagai fasilitator yang selalu mengawasi dan mengarahkan transisi kelompok agar suasana kelas tetap terkendali.

c. Penyelesaian

Guru memberikan evaluasi terhadap proses kelompok dan juga pemahaman mereka terhadap materi. ${ }^{16}$

\footnotetext{
${ }^{16}$ John Holt, "Jigsaw: Tips on Implementation,"www.jigsaw.org/tips.htm, diakses pada 15 Mei 2011.
} 


\section{Prestasi Belajar al-Qur'an Hadis Materi Menghaial Surat- Surat Pendek}

Menurut Kamus Besar Bahasa Indonesia, prestasi adalah hasil yang telah dicapai (dari yang telah dilakukan, dikerjakan, dan lainnya). Sedangkan belajar adalah berusaha memperoleh kepandaian atau ilmu. ${ }^{17}$ Belajar, menurut Shaleh Abdul Aziz dan Abdul Aziz Abdul Majid dalam bukunya, at-Tarbiyah wa Thuruqut Tadris, mendefinisikan belajar adalah belajar adalah perubahan pada hati (jiwa) si pelajar berdasarkan pengetahuan yang sudah dimiliki menuju perubahan baru. ${ }^{18}$

Sementara itu, Laster D. Crow dan Alice Crow mendefinisikan belajar adalah sebagai berikut: The term learning can be interpreted as: 1) the process by which changes are made, or; 2) the changes themselves that result from engaging in the learning process. ${ }^{19}$ Artinya: pengertian belajar dapat diinterpretasikan sebagai (a) suatu proses yang terjadi secara sengaja, atau (2) suatu perubahan yang terjadi dengan sendirinya sebagai akibat dari bentuk proses belajar. Sementara itu, Elizabeth B. Hurlock mendefinisikan belajar adalah learning is development that comes from exercise and afford. ${ }^{20}$ Artinya, belajar adalah suatu bentuk perkembangan yang timbul dari latihan dan usaha. Sedangkan prestasi belajar, adalah penilaian hasil belajar yang dinyatakan dalam bentuk angka, huruf, atau kalimat yang mencerminkan hasil yang sudah dicapai siswa dalam periode tertentu. ${ }^{21}$ WS. Winkel mengemukakan prestasi belajar merupakan hasil belajar yang ditampakkan oleh siswa berdasarkan kemampuan internal yang diperolehnya sesuai dengan tujuan instruksional.

\footnotetext{
${ }^{17}$ Pusat Bahasa, Kamus Besar Bahasa Indonesia, edisi III (Jakarta: Balai Pustaka, 2007), 895.

${ }^{18}$ Shaleh Abdul Aziz \& Abdul Aziz Abdul Majid, At-Tarbiyah wa Thuruqut Tadris, Juz I (Mesir: Darul Ma’arif, t.th.), 169.

${ }^{19}$ Laster D. Crow \& Alice Crow, General Psychology (New York: tpt, t.th.), 188.

${ }^{20}$ Elizabeth B. Hurlock, Child Development (Tokyo: MC. Graw Hill Book Company, t.th.), 20.

${ }^{21}$ WS. Winkel, Psikologi Pendidikan dan Evaluasi Belajar (Jakarta: Gramedia, 1996), 36.
} 
Selanjutnya, al-Qur'an ialah firman Allah yang berupa wahyu yang disampaikan oleh Jibril kepada Nabi Muhammad Saw., di dalamnya mengandung ajaran pokok yang dapat dikembangkan untuk keperluan seluruh aspek kehidupan melalui ijtihad. Ajaran yang terkandung dalam al-Qur'an, yaitu akidah dan syariah. Dan Hadis ialah perkataan, perubahan dan pengakuan Rasul Allah Swt. Hadis merupakan sumber ajaran kedua sesudah al-Qur'an dan berisi tentang akidah dan syari'ah, serta merupakan kemaslahatan hidup manusia dalam segala aspeknya untuk membina umat manusia menjadi manusia seutuhnya atau manusia pendidikan. ${ }^{22}$

Mata pelajaran al-Qur'an Hadis di Madrasah Ibtidaiyah adalah salah satu mata pelajaran PAI yang menekankan pada kemampuan membaca dan menulis al-Qur'an dan Hadis dengan benar, serta hafalan terhadap surat-surat pendek dalam al-Qur'an, pengenalan arti atau makna sederhana dari surat-surat pendek tersebut dan HadisHadis tentang akhlak terpuji untuk diamalkan dalam kehidupan sehari-hari melalui keteladanan dan pembiasaan. ${ }^{23}$

Ruang lingkup materi mata pelajaran al-Qur'an Hadis di Madrasah Ibtidaiyah meliputi:

a. Pengetahuan dasar membaca dan menulis al-Qur'an yang benar sesuai dengan kaidah ilmu tajwid.

b. Hafalan surat-surat pendek dalam al-Qur'an dan pemahaman sederhana tentang arti dan makna kandungannya serta pengamalannya melalui keteladanan dan pembiasaan dalam kehidupan sehari-hari. Dalam penelitian ini indikator dari hafalan adalah:

1) Dapat menghafal sesuai bacaan nun mati.

2) Dapat menghafal sesuai tanwin.

3) Dapat menghafal sesuai mad.

${ }^{22}$ Zakiah Daradjat, Ilmu Pendidikan Islam (Jakarta: Bumi Aksara, 2002), 30.

${ }^{23}$ Peraturan Menteri Agama Republik Indonesia No. 2 Tahun 2008 tentang Standar Kompetensi Lulusan dan Standar Isi Pendidikan Agama Islam dan Bahasa Arab di Madrasah, 19. 
4) Dapat menghafal sesuai bacaan qolqolah.

5) Dapat menghafal sesuai bacaan waqaf.

c. Pemahaman dan pengamalan melalui keteladanan dan pembiasaan mengenai Hadis-Hadis yang berkaitan dengan kebersihan, niat, menghormati orang tua, persaudaraan, silaturahmi, takwa, menyayangi anak yatim, salat berjamaah, ciri-ciri orang munafik, dan amal salih. ${ }^{24}$

Dalam penelitian ini materi yang diajarkan adalah materi suratsurat pendek terutama pada Surat al-Lahab dan Surat al-'Adiyat. Jadi, secara sederhana prestasi belajar al-Qur'an materi menghafal surat-surat pendek adalah penguasaan keterampilan dan pengetahuan yang dimiliki siswa dalam al-Qur'an materi menghafal surat-surat pendek yang ditunjukkan dengan tes atau nilai yang diberikan oleh guru dan kemampuan perubahan sikap atau tingkah laku yang diperoleh siswa melalui kegiatan belajar.

\section{Alat-alat Intuk Mengukur Prestasi Belajar al-(Qur'an Hadis Materi Menghafal Surat-Surat Pendek}

Kegiatan penilaian dan pengujian pendidikan merupakan salah satu mata rantai yang menyatu terjalin di dalam proses pembelajaran siswa. Mudjijo berpendapat bahwa tes sebenarnya adalah salah satu program penilaian. ${ }^{25}$ Selanjutnya mengatakan bahwa cara melancarkan tes inilah yang paling banyak dilakukan oleh para pendidik dalam melakukan penilaian terhadap hasil belajar peserta didiknya. Dengan demikian, peranan tes sebagai salah satu alat atau teknik penilaian pendidikan khususnya dalam proses belajar mengajar sangat penting. ${ }^{26}$ "Achievement tests may be described as those that attempt to measure the attainment

\footnotetext{
${ }^{24}$ Ibid., 20.

${ }^{25}$ Mudjijo, Tes Hasil Belajar (Jakarta: Bumi Aksara, 1995), 1.

${ }^{26}$ Ibid., 2.
} 
of pupils in the various important objectives or areas of the curriculum". ${ }^{27}$ Maksudnya tes prestasi digambarkan sebagai suatu alat untuk mengukur hasil yang telah dicapai oleh siswa dalam pembelajaran. Saifudin Azwar berpendapat tes sebagai pengukur prestasi sebagaimana oleh namanya, tes prestasi belajar bertujuan untuk mengukur prestasi atau hasil yang telah dicapai oleh siswa dalam belajar. ${ }^{28}$

Penilaian atau tes itu berfungsi untuk memperoleh umpan balik dan selanjutnya digunakan untuk memperbaiki proses belajar mengajar, maka penilaian itu disebut penilaian formatif. Tetapi jika penilaian itu berfungsi untuk mendapatkan informasi sampai mana prestasi atau penguasaan dan pencapaian belajar siswa yang selanjutnya diperuntukkan bagi penentuan lulus tidaknya seorang siswa maka penilaian itu disebut penilaian sumatif. ${ }^{29}$

Jika dilihat dari segi alatnya, penilaian hasil belajar dapat dibedakan menjadi dua macam, yaitu tes dan non tes. Tes ada yang diberikan secara lisan (menuntut jawaban secara lisan) ini dapat dilakukan secara individu maupun kelompok, ada tes tulisan (menuntut jawaban dalam bentuk tulisan), tes ini ada yang disusun secara objektif dan uraian, dan tes tindakan (menuntut jawaban dalam bentuk perbuatan). Sedangkan non tes sebagai alat penilaiannya mencakup observasi, kuesioner, wawancara, skala sosiometri, studi kasus. ${ }^{30}$

\footnotetext{
${ }^{27}$ Charles E. Sukinner, Essential of Education Psychology (New York: Prentice-Hall), 446.

${ }^{28}$ Saifuddin Azwar, Tes Prestasi dan Pengembangan Pengukuran Prestasi Belajar (Yogyakarta: Pustaka Pelajar, 1996), 8.

${ }^{29}$ Ibid., 11-12.

${ }^{30}$ Nana Sudjana, Penilaian Hasil Proses Belajar Mengajar (Bandung: Remaja Rosdakarya, 2001), 5 .
} 


\section{Faktor-faktor yang Mempengaruhi Prestasi Belajar al-Qur’an Hadis Materi Menghaial Surat-Surat Pendek}

Abu Ahmadi dan Widodo Supriyono mengemukakan beberapa hal yang mempengaruhi hasil belajar atau prestasi belajar, yaitu:

a. Faktor internal (dari dalam) meliputi:

1) Faktor jasmaniah (fisiologi) baik yang bersifat bawaan maupun yang diperoleh. Yang termasuk faktor ini misalnya penglihatan, pendengaran, struktur tubuh, dan sebagainya.

2) Faktor psikologis baik yang bersifat bawaan maupun yang diperoleh terdiri atas:

a) Faktor intelektif yang meliputi: faktor potensial yaitu kecerdasan dan bakat. Faktor kecakapan nyata yaitu prestasi yang telah dimiliki.

b) Faktor non intelektif, yaitu unsur-unsur kepribadian tertentu seperti sikap kebiasaan, minat, kebutuhan, motivasi, emosi penyesuaian diri.

3) Faktor kematangan fisik maupun psikis.

4) Faktor lingkungan spiritual atau keamanan.

b. Faktor eksternal (dari luar) yang meliputi:

1) Faktor sosial yang terdiri atas:

a) Lingkungan keluarga.

b) Lingkungan sekolah.

c) Lingkungan masyarakat.

d) Lingkungan kelompok.

2) Faktor budaya seperti adat istiadat, ilmu pengetahuan, teknologi, kesenian.

3) Faktor lingkungan fisik seperti fasilitas rumah, fasilitas belajar, iklim. ${ }^{31}$

\footnotetext{
${ }^{31}$ Abu Ahmadi \& Widodo Supriyono, Psikologi Belajar, Cet. II (Jakarta: Rineka
} 


\section{Usaha untuk Meningkatkan Prestasi Belajar al-(pur’an Hadis: Materi Menghaial Surat-Surat Pendek}

Untuk meningkatkan hasil belajar siswa ada beberapa cara yang bisa dilakukan sebagai berikut:

a. Menyediakan pengalaman langsung tentang objek-objek nyata bagi anak. Pengalaman langsung merupakan pengalaman yang diperoleh anak dengan menggunakan semua indranya, yaitu melihat, menyentuh, mendengar, meraba dan merasa. Melalui pengalaman seperti anak-anak membangun pengetahuannya dengan cara memperlakukan atau memanipulasi objek, mengamati peristiwaperistiwa atau kejadian, berinteraksi dengan manusia dan lingkungan sekitarnya. Melalui pengalaman langsung anak mengembangkan keterampilan mengamati, membandingkan, menghitung, bermain peran, mengemukakan perasaan, dan gagasannya. Misalnya pada pembelajaran menghafal siswa melekukkan latihan langsung menghafal dengan melihat cara menghafal guru yang sudah sesuai dengan kaidah membaca dengan benar.

b. Menciptakan kegiatan sehingga anak menggunakan semua pemikirannya. Kegiatan-kegiatan yang dikembangkan dalam pembelajaran terpadu menentang anak untuk menggunakan semua pemikiran dan pemahamannya. Dengan demikian, dalam pembelajaran terpadu aktivitas mental anak terlibat.

c. Mengembangkan kegiatan sesuai dengan minat-minat anak. Kegiatan-kegiatan yang dikembangkan dalam pembelajaran terpadu harus relevan dengan minat anak, karena minat anak merupakan sumber ide yang potensial untuk menentukan tema. Jika minat anak dipertimbangkan dalam memilih tema, maka anak akan menunjukkan pemahaman yang lebih baik

d. Membantu anak mengembangkan pengetahuan dan keterampilan baru yang didasarkan pada hal-hal yang telah mereka 
ketahui dan telah dapat mereka lakukan sebelumnya. Tema yang dipilih untuk pembelajaran terpadu harus mempertimbangkan pengetahuan dan keterampilan yang telah dimiliki anak, sehingga memudahkan mereka untuk mempelajari hal-hal baru, dengan demikian pemilihan tema harus dimulai dari tema yang sudah dikenal anak.

e. Menyediakan kegiatan dan kebiasaan yang ditujukan untuk mengembangkan semua aspek pengembangan kognitif, sosial, emosional, fisik afeksi dan estetis dan agama. Tema sebagai fokus dalam pembelajaran terpadu memungkinkan untuk mengembangkan semua aspek perkembangan melalui kegiatan-kegiatan belajar yang relevan.

f. Mengakomodasikan kebutuhan anak-anak untuk melakukan aktivitas fisik, interaksi sosial, kemandirian dan mengembangkan harga diri yang positif. Setiap anak mempunyai kebutuhan yang berbeda yang berkaitan dengan aspek fisik, sosial, afeksi, emosi dan intelektual. Melalui pembelajaran terpadu kebutuhankebutuhan tersebut sangat mungkin untuk dipenuhi karena pembelajaran terpadu menyediakan kegiatan belajar yang bervariasi.

g. Memberikan kesempatan menggunakan bermain sebagai wahana belajar. Bermain merupakan wahana yang baik untuk mengembangkan semua aspek perkembangan anak. Melalui bermain anak melakukan proses belajar yang menyenangkan, suka rela dan spontan. Melalui bermain, anak-anak juga membentuk konsep-konsep yang lebih abstrak. ${ }^{32}$

\section{Metode Jigsaw untuk Peningkatan Prestasi Belajar}

Pembelajaran kooperatif merujuk pada berbagai macam metode pengajaran dimana siswa bekerja dalam kelompok-kelompok kecil untuk saling membantu satu sama lainnya dalam mempelajari materi

\footnotetext{
${ }^{32}$ Masitoh, et.al, Strategi Pembelajaran (Jakarta: Universitas Terbuka, 2004), 124.
} 
pelajaran. Dalam kelas kooperatif, siswa dapat saling membantu, saling mendiskusikan dan berargumentasi untuk mengarah pengetahuan yang mereka kuasai saat itu dan menutup kesenjangan dalam pemahaman masing-masing. Cara belajar kooperatif jarang sekali menggantikan pengajaran yang diberikan oleh guru, tetapi lebih seringnya menggantikan pengaturan tempat duduk yang individual, cara belajar yang individual dan dorongan yang individul. Apabila diatur dengan baik, siswa-siswa dalam kelompok kooperatif akan belajar satu sama lain untuk memastikan bahwa tiap orang dalam kelompok telah menguasai konsep-konsep yang telah dipikirkan. ${ }^{33}$

Model pembelajaran jigsaw merupakan model pembelajaran kooperatif dengan kelompok secara heterogen dan setiap kelompok bertanggung jawab untuk mempelajari bagian tertentu. Tujuan kelompok dan tanggung jawab individu adalah dalam memberikan insentif kepada siswa untuk saling membantu satu sama lain dan untuk saling mendorong melakukan usaha maksimal. Jika nilai siswa cukup baik sebagai kelompok, dan kelompok hanya akan berhasil dengan memastikan bahwa semua anggotanya telah mempelajari materinya, maka anggota akan termotivasi untuk saling mengajar. Siswa yang saling memberikan penjelasan secara terperinci satu sama lain adalah siswa yang paling banyak belajar. Dengan termotivasi untuk saling mengajar ini menunjukkan langkah awal adanya minat untuk belajar. ${ }^{34}$

Pembelajaran dengan metode jigsaw para siswa diberi tugas untuk menghafal beberapa surat-surat pendek dan diberikan lembar ahli yang terdiri atas topik-topik yang berbeda, dan ini menjadi fokus perhatian masing-masing anggota tim saat mereka membaca surat-surat pendek. Jadi, setiap siswa harus menguasai materi yang menjadi bagiannya supaya bisa mengajari teman satu timnya mengenai cara menghafal dengan benar.

\footnotetext{
${ }^{33}$ Slavin, Cooperative Learning, 4.

${ }^{34}$ Ibid., 237.
} 
Metode Jigsaw dapat menumbuhkan motivasi belajar pada siswa dengan sendirinya, karena dalam pembelajaran ini memberikan kesempatan kepada semua siswa untuk terlibat secara aktif dalam proses berpikir dan kegiatan belajar. Belajar dengan motivasi belajar akan mendorong siswa belajar lebih baik dari pada tanpa motivasi sehingga secara tidak langsung prestasi al-Qur'an Hadis materi pokok menghafal suratsurat pendek siswa bisa meningkat.

Beberapa hasil penelitian menunjukkan manfaat pembelajaran kooperatif bagi siswa dengan hasil belajar rendah antara lain sebagai berikut:

a. Pemahaman yang lebih mendalam.

b. Motivasi belajar yang lebih besar.

c. Hasil belajar lebih tinggi.

Ketika para siswa bekerja, bersama-sama untuk meraih sebuah tujuan kelompok, mereka akan mengekspresikan norma-norma yang baik dalam melakukan apapun yang diperlukan untuk keberhasilan kelompok. Para siswa di dalam kelas-kelas pembelajaran kooperatif merasa bahwa teman sekelas mereka ingin agar mereka belajar. Pembelajaran menjadi aktivitas yang bisa membuat para siswa lebih baik prestasi menghafalnya. ${ }^{35}$

\section{Penutup}

Belajar mengajar adalah suatu kegiatan yang bernilai edukatif. Nilai edukatif mewarnai interaksi yang terjadi antara guru dan anak didik. Interaksi yang bernilai edukatif dikarenakan kegiatan belajar mengajar yang dilakukan, diarahkan untuk mencapai tujuan tertentu yang telah dirumuskan sebelum pengajaran dilakukan. ${ }^{36}$ Proses belajar mengajar yang dilakukan dalam kelas merupakan aktivitas mentransformasikan ilmu pengetahuan, sikap dan keterampilan. Pengajar diharapkan mampu

\footnotetext{
${ }^{35}$ Ibid., 35.

${ }^{36}$ Syaiful Bahri Djamarah \& Aswan Zain, Strategi Belajar Mengajar (Jakarta: Rineka Cipta, 2002), 1.
} 
mengembangkan kapasitas belajar, kompetensi dasar, dan potensi yang dimiliki siswa secara penuh. ${ }^{37}$

Selain itu mengajar juga sebagai usaha untuk menciptakan sistem lingkungan yang mengoptimalkan kegiatan belajar mengajar dalam arti ini adalah usaha menciptakan suasana belajar bagi siswa secara optimal. Yang menjadi pusat perhatian dalam proses belajar mengajar ialah siswa. Pendekatan menghasilkan strategi yang disebut student center strategis. Strategi belajar mengajar yang berpusat pada peserta didik. ${ }^{38}$ Untuk mendapatkan suatu pembelajaran aktif kreatif dan menyenangkan sekaligus meningkatkan penghayatan terhadap keimanan dan realisasinya dalam realitas hubungan sosial bagi peserta didik, maka model pembelajaran Jigsaw Learning menjadi salah satu model pembelajaran yang dapat mewujudkan tujuan itu semua. Jigsaw learning dapat di gunakan dalam semua mata pelajaran tidak terkecuali dalam pembelajaran al-Qur'an Hadis terutama materi menghafal surat-surat pendek yang lebih menitik beratkan tujuannya kepada kemampuan siswa menghafal dengan benar sesuai dengan kaidah tajwid maupun mahroj-nya. Jigsaw merupakan metode pembelajaran kooperatif yang memungkinkan masing-masing siswa satu kelompok mengkhususkan diri pada suatu materi pembelajaran. Dalam strategi ini guru memperhatikan latar belakang pengalaman siswa dan membantu sesama agar bahan pelajaran menjadi lebih bermakna. ${ }^{39}$ Dengan memberikan banyak kesempatan siswa untuk aktif belajar kelompok dalam menghafal surat-surat pendek menjadikan kemampuan siswa dalam membaca dan menghafal menjadi baik karena terjadi proses tukar pikiran dan saling melengkapi bacaan dan hafalan siswa.

\footnotetext{
${ }^{37}$ Martinis Yamin, Pengembangan Kompetensi Pembelajaran (Jakarta: UI Press, 2004), 160.

${ }^{38}$ W. Gulo, Strategi Belajar Mengajar (Jakarta: PT Grasindo, 2002), 4-6.

${ }^{39}$ Ibid., 69.
} 


\section{Daítar Pustaka}

Ahmadi, Abu \& Widodo Supriyono. Psikologi Belajar. Cet. II. Jakarta: Rineka Cipta, 2004.

Arikunto, Suharsimi. Penelitian Tindakan Kelas. Jakarta: Bumi Aksara, 2006.

. Prosedur Penelitian: Sebuah Pendekatan Praktik. Jakarta: PT. Rineka Cipta, 2004.

Aziz., Shaleh Abdul \& Abdul Aziz Abdul Majid. At-Tarbiyah wa Thuruqut Tadris. Juz I. Mesir: Darul Ma'arif, t.t.

Azwar, Saifuddin. Tes Prestasi dan Pengembangan Pengukuran Prestasi Belajar. Yogyakarta: Pustaka Pelajar, 1996.

Basrowi \& Suwandi. Prosedur Penelitian Tindakan Kelas. Bogor: Penerbit Ghalisa Indonesia, 2008

Budingrah, Hermin. Kooperatif Learning. Bandung: Pustaka Setia, 2004.

Crow, Laster D \& Alice Crow. General Psychology. New York: tpt, t.t.

Daradjat, Zakiah. Ilmu Pendidikan Islam. Jakarta: Bumi Aksara, 2002.

Djamarah, Syaiful Bahri \& Aswan Zain. Strategi Belajar Mengajar. Jakarta: Rineka Cipta, 2002.

. Pendidik dan Anak Didik dalam Interaksi Edukatif. Jakarta: Rineka Cipta, 2000.

Gulo, W. Strategi Belajar Mengajar. Jakarta: PT Grasindo, 2002.

Holt, John. "Jigsaw: Tips on Implementation." www.jigsaw.org/tips.htm. Diakses pada 1 oktober 2010.

Hurlock, Elizabeth B. Child Development. Tokyo: MC. Graw Hill Book Company, t.th.

Kartono, Kartini. Psikologi Anak: Psikologi Perkembangan. Bandung: Mandar Maju, 1995. 
Lie, Anita. Cooperative Learning. Jakarta: Gramedia Widiasarana Indonesia, 2004.

Margono. Metodologi Penelitian Pendidikan. Jakarta: Rineka Cipta, 2000.

Masitoh, et.al. Strategi Pembelajaran. Jakarta: Universitas Terbuka, 2004.

Mudjijo. Tes Hasil Belajar. Jakarta: Bumi Aksara, 1995.

Muslich, Masnur. Melaksanakan PTK Penelitian Tindakan Kelas itu Mudah. Jakarta: PT Bumi Aksara, 2009.

Negoro, Sutrinah Tirto. Anak Super Normal dan Pro Pendidikan. Jakarta: Bina Aksara, 1984.

Peraturan Menteri Agama Republik Indonesia No. 2 Tahun 2008, Tentang Standar Kompetensi Lulusan dan Standar Isi Pendidikan Agama Islam dan Bahasa Arab di Madrasah.

Peraturan Pemerintah No. 19 Tahun 2005 tentang Standar Nasional Pendidikan.

Pusat Bahasa. Kamus Besar Bahasa Indonesia. Edisi III. Jakarta: Balai Pustaka, 2007.

Riyanto, Yatim. Metodologi Penelitian suatu Tindakan Dasar. Surabaya: Sie Surabaya, 1996.

Siberrnen, Mel. 101 Strategi Pembelajaran Aktif Active Learning. terj. Sarjuli dan Azfat Ammar. Jakarta: Yakpendis, 2001.

Slameto. Belajar dan Faktor-faktor yang Mempengaruhinya. Jakarta: Rineka Cipta, 1995.

Slavin, Robert E. Cooperative Learning. Bandung: Nusa Media, 2008.

Soenarjo, et.al. Al-Quran dan Terjemahnya. Jakarta: Depag RI, 2005.

Sudjana, Nana. Penilaian Hasil Proses Belajar Mengajar. Bandung: Remaja Rosda Karya, 2001.

Sugianto, Ilham Agus. Kiat Praktis Menghafal al-Qur'an. Bandung: Mujahid, 2004. 
Sugiono. Metodelogi Penelitian Pendidikan Pendekatan Kuantitatif, Kualitatif dan R \& D. Bandung: Alfabeta, 2007.

Sukinner, Charles E. Essential of Education Psychology. New York: Prentice Hall, 1958.

Syah, Muhibbin. Psikologi Pendidikan dengan Pendekatan Baru. Bandung: Remaja Rosda Karya, 1997.

Undang-Undang No. 20 Tahun 2003 Tentang Sistem pendidikan Nasional. Walgito, Bimo. Bimbungan dan Penyuluhan di Sekolah. Yogyakarta: Andi Offset, 2000.

Wiriatmadja. Metode Penelitian Tindakan Kelas. Bandung: Remaja Rosda Karya, 2005.

Yamin, Martinis. Pengembangan Kompetensi Pembelajaran. Jakarta: UI Press, 2004. 